\title{
Taxonomic status of two morphotypes of Coryphaena hippurus (Perciformes: Coryphaenidae)
}

\author{
Alan Bonner ${ }^{1}$, Michelle R. Duarte ${ }^{1}$, Rosa C. C. L. Souza ${ }^{1}$, Cassiano Monteiro-Neto $^{2}$ and \\ Edson P. Silva ${ }^{1}$
}

Two Coryphaena hippurus morphotypes (dourado and palombeta) are found along the Brazilian coast and are considered by Rio de Janeiro's fisherman and fishmongers as two different species. Furthermore, these morphotypes are commercialized under different values and suffer different fishing pressure. Therefore, a definition of their taxonomic status is an important economic and biological matter. In order to investigate this problem, allozyme electrophoresis method was undertaken for seventeen loci on 117 individuals of C. hippurus sampled at Cabo Frio/RJ (Brazil). The data indicate homogeneity between the morphotypes gene pools. Nevertheless, differences were found for genetic variation among dourado and palombeta, especially due to alcohol dehydrogenase locus. Natural selection hypothesis is discussed in explaining these findings.

Keywords: Alcohol dehydrogenase, Allozyme electrophoresis, Biochemical systematics, Fishery resources, Genetic variation.

Dois morfotipos de Coryphaena hippurus (dourado e palombeta) encontrados ao longo da costa brasileira são considerados espécies diferentes por pescadores e mercadores das regiões de desembarque do estado do Rio de Janeiro. Além disso, esses morfotipos são comercializados por valores diferentes e sofrem diferentes pressões de pesca. Desta forma, a definição do status taxonômico desses morfotipos é importante, tanto em termos econômicos quanto biológicos. A fim de investigar esse problema foi utilizado o método de eletroforese de aloenzimas com a amostragem de dezessete loci para 117 indivíduos dos dois morfotipos de C. hippurus obtidos em desembarques pesqueiros na região de Cabo Frio/RJ (Brasil). Os dados indicaram uma homogeneidade entre os conjuntos gênicos dos morfotipos. A despeito disso, diferenças entre os conjuntos gênicos de dourado e palombeta foram encontradas, devido, especialmente, ao locus álcool desidrogenase. A hipótese de seleção natural é discutida como possível explicação para esses resultados.

Palavras-chave: Desidrogenase do octanol, Eletroforese de aloenzimas, Recursos pesqueiros, Sistemática bioquímica, Variação gênica.

\section{Introduction}

Coryphaena hippurus Linnaeus, 1758 is an oceanic fish that has been exploited by commercial and sport fishing off the coast of Brazil (Amorim et al., 2011; Nóbrega et al., 2015). In the state of Rio de Janeiro (RJ), for example, fishing for this species reached 1,681 tons in 2012, representing $2 \%$ of the total marine fishery production in the state for that year (Fundação Instituto da Pesca do Estado do Rio de Janeiro; FIPERJ, 2013). Due to its good swimming capabilities, $C$. hippurus can be found in the epipelagic zone of tropical and subtropical waters (Gibbs Jr., Collette, 1959), and due to its very active migratory habits, the stocks for this species are expected to be very large (Díaz-Jaimes et al., 2010).

In parts of the Brazilian coast, fishermen at fish landings recognise two morphotypes of $C$. hippurus. In Rio de Janeiro the region, for example, the larger morphotype is referred to as dourado, whereas the smaller morphotype is known as the palombeta (designation which is also used for the species Chloroscombrus chrysurus occurring in coastal waters of the southwestern Atlantic). The former morphotype has a greater commercial value in the various fish markets at this location (personal observation). Therefore, defining the taxonomic status of these morphotypes is important for both commercial interests and from the point of view of fish biology, given that the management and conservation of this resource depend on the estimated size of the stocks, which in turn depends on correctly defining the morphotypes as belonging to the same species (von der Heyden et al., 2014).

Biochemical systematics using allozyme electrophoresis is a set of techniques that can detect biochemical differences between groups (populations, morphotypes, subspecies, etc.)

\footnotetext{
${ }^{1}$ Laboratório de Genética Marinha e Evolução, Departamento de Biologia Marinha, Universidade Federal Fluminense. Outeiro São João Batista s/n, Centro, 24.001-970 Niteroi, RJ, Brazil. (AB) abscosta@id.uff.br (corresponding author), (MRD) michellerezendeduarte@ yahoo.com.br, (RCCLS) rcclsouza@yahoo.com.br, (EPS) gbmedson@vm.uff.br

${ }^{2}$ Laboratório de Biologia do Nécton e Ecologia Pesqueira, Departamento de Biologia Marinha, Universidade Federal Fluminense. Outeiro São João Batista s/n, Centro, 24.001-970 Niteroi, RJ, Brazil. monteironeto@gmail.com
} 
(Moritz, Hillis, 1996; Duarte et al., 2016). These techniques can help resolve taxonomic issues associated with various groups of marine organisms (Knowlton, 2000), including fish (Berrebi, 2015; Nahar et al., 2015). This method has previously been applied to $C$. hippurus in studies of the genetic structure of stocks of the species found in the Atlantic and the Mediterranean islands (Oxenford, Hunte, 1986; Pla, Pujolar, 1999), as well as to define the taxonomic status of two species of the genus Coryphaena that are found in the Canary Islands (Pujolar, Pla, 2002).

In the present study, the allozyme electrophoresis method was used to evaluate the taxonomic status of two morphotypes of $C$. hippurus, which are delivered at the fish landings of Cabo Frio, RJ. The null hypothesis to be tested is that the morphotypes represent only a single species. Also, basic population genetics parameters (polymorphism, effective number of alleles, gene frequencies, and heterozygosities) are estimated for both morphotypes.

\section{Material and Methods}

Samples of one hundred and seventeen individuals of Coryphaena hippurus were obtained from fish landings at Cabo Frio/RJ (Brazil), between November/2013 and April/2014. Thirty two samples of dourados showed an average weight of $9345.63 \mathrm{~g}$ (ranging from to 4200 to $17420 \mathrm{~g}$ ) and average total size of $128.72 \mathrm{~cm}$ (ranging from to 97 to $198 \mathrm{~cm}$ ). Eighty five samples of palombetas showed an average weight of $1342.26 \mathrm{~g}$ (ranging from to 400 to $4090 \mathrm{~g}$ ) and average total size of $59.18 \mathrm{~cm}$ (ranging from to 42 to $84 \mathrm{~cm}$ ). Fig. 1 shows the sampling sites and respective coordinates are found in figure legend. Once landed, the specimens were dissected. Extracts of five tissues (liver, heart, eye, muscle and gonad) were placed in microtubes and kept at $-20^{\circ} \mathrm{C}$ until the electrophoresis process.

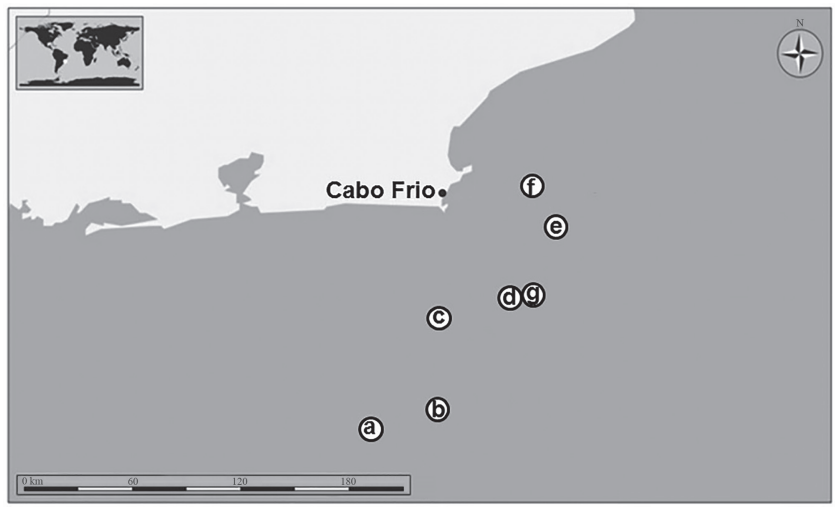

Fig. 1. Map of Cabo Frio/RJ region, with the fishing locations of the samples. a. $24^{\circ} 04^{\prime} 33.55^{\prime \prime} \mathrm{S}$ and $42^{\circ} 25^{\prime}$ $55.07^{\prime \prime} \mathrm{W}$; b. $24^{\circ} 01^{\prime} 10.60^{\prime \prime} \mathrm{S}$ and $42^{\circ} 00^{\prime} 21.23^{\prime \prime} \mathrm{W}$; c. $23^{\circ}$ $30^{\prime} 47.88^{\prime \prime} \mathrm{S}$ and $42^{\circ} 00^{\prime} 10.47^{\prime \prime} \mathrm{W}$; d. $23^{\circ} 23^{\prime} 43.60^{\prime \prime} \mathrm{S}$ and $41^{\circ} 39^{\prime} 41.28^{\prime \prime} \mathrm{W}$; e. $23^{\circ} 04^{\prime} 30.69^{\prime \prime} \mathrm{S}$ and $41^{\circ} 19^{\prime} 50.13^{\prime \prime} \mathrm{W}$; f. $23^{\circ} 01^{\prime} 59.84^{\prime \prime} \mathrm{S}$ and $41^{\circ} 26^{\prime} 41.09^{\prime \prime} \mathrm{W}$; g. $23^{\circ} 23^{\prime} 51.60^{\prime \prime}$ $\mathrm{S}$ and $41^{\circ} 39^{\prime} 9.87^{\prime \prime} \mathrm{W}$.
Horizontal gel electrophoresis was performed by standard methods using 12.5\% starch gels (Harris, Hopinkson, 1978). The gels were stained for 30 enzyme systems using the five tissues. Eleven enzymes gave useful results for three tissues (liver, muscle and gonad). These systems were interpreted as the expression of seventeen gene loci (Tab. 1). The buffer systems used were discontinuous lithium hydroxide $\mathrm{pH} 8.0$ (Selander et al., 1971) for all enzyme systems. Alleles were labelled alphabetically following decreasing electrophoretic mobility.

Tab. 1. Enzymatic systems sampled in this work, with their abbreviations, commission number $\left(\mathrm{N}^{\circ} \mathrm{EC}\right)$, number of subunits $\left(\mathrm{N}^{\circ} \mathrm{sub} ; * 1=\right.$ monomeric; $2=$ dimeric; $4=$ tetrameric), number of interpreted loci, ( $\mathrm{N}^{\circ}$ loci) and tissue used for each system.

\begin{tabular}{|c|c|c|c|c|c|}
\hline Abbreviation & Enzime & $\mathrm{N}^{\circ} \mathrm{EC}$ & No sub.* & $\mathrm{N}^{\circ}$ loci & Tissue \\
\hline$\alpha-E s t$ & Esterase, alpha & 3.1.1.1 & 1 & 3 & Liver \\
\hline$\beta$-Est & Esterase, beta & 3.1.1.1 & 1 & 3 & Gonad \\
\hline G6pd & $\begin{array}{l}\text { Glucose-6-phosphate } \\
\text { dehydrogenase }\end{array}$ & 1.1 .1 .49 & 2 & 1 & Gonad \\
\hline$L d h$ & Lactate dehydrogenase & 1.1 .1 .27 & 4 & 1 & Muscle \\
\hline$M d h$ & Malate dehydrogenase & 1.1 .1 .37 & 2 & 1 & Muscle \\
\hline$M e$ & Malic enzyme & 1.1 .1 .40 & 4 & 2 & Gonad \\
\hline Odh & Octanol dehydrogenase & 1.1.1.1 & 2 & 2 & Gonad \\
\hline Pgi & $\begin{array}{l}\text { Glucose phosphate } \\
\text { isomerase }\end{array}$ & 5.3.1.9 & 2 & 1 & Gonad \\
\hline Pgm & Phospoglucomutase & 2.7.5.1 & 1 & 1 & Muscle \\
\hline Sod & Superoxide dismutase & 1.15.1.1 & 1 & 1 & Muscle \\
\hline Xod & Xanthine oxidase & 1.2.3.2 & 2 & 1 & Liver \\
\hline
\end{tabular}

Data analyses were carried out using the software packages GENEPOP 4.2 (Rousset, 2008), BYOSIS-2 (Swofford, Selander, 1997), Fstat 2.9.3.2. (Goudet, 2001) and Microsoft Excel 2007 for Windows. Genetic variation was estimated at morphotype level through percentage of polymorphic loci, effective number of alleles (Ae; Kimura, Crow, 1964) and the mean number of observed and expected heterozygotes $\left(\mathrm{H}_{\mathrm{OBS}}\right.$ and $\mathrm{H}_{\mathrm{EXP}}$ respectively) per locus (Nei, 1978).

Genotypic frequencies observed for each morphotype and also taking dourado and palombeta as a single group were tested for conformation to Hardy-Weinberg equilibrium using an exact test (Rousset, Raymond, 1995). The P-values obtained by the exact Markov chain method (Guo, Thompson, 1992) were corrected for multiple testing with the Bonferroni technique (Rice, 1989). Linkage disequilibrium was analyzed by performing exact tests using a Markov chain method and correcting P-values obtained with the Bonferroni technique (Rice, 1989). The null hypothesis tested was that genotypes at one locus are independent from genotypes at the other locus within each morphotype.

F-statistics analysis was used to partition genetic variation within morphotype (f) and between morphotypes ( $\theta)$ components using Weir and Cockerham's (1984) 
method, which takes into account the differences in size among samples. Confidence intervals by bootstrapping over loci were obtained. Significance tests of F-estimates were carried out as described by Krebs (1999). The mean $\theta$ value was used to calculate the average number of migrants being exchange between the morphotypes per generation $(\mathrm{Nm})$ using the equation $\mathrm{Nm}=((1 / \theta)-1) / 4$, and genetic identity were calculated according to Nei (1972).

\section{Results}

For a mean sample size of 16 individuals of the dourado morphotype and 22.8 individuals of the palombeta morphotype (overall mean of 19.4), we found an average of 2.95 alleles per locus, including 2.7 for the dourado morphotype and 3.2 for the palombeta morphotype. The mean polymorphism rate observed for both morphotypes was high $(94.1 \%)$. Table 2 shows the gene frequencies and the expected and observed heterozygosities for each of the 17 loci.

Tab. 2. Allele frequencies $\left(\mathrm{N}=\right.$ sample size for each locus; $\mathrm{H}_{\mathrm{OBS}}$ = observed heterozygosis; $\mathrm{H}_{\mathrm{EXP}}=$ expected heterozygosis).

\begin{tabular}{|c|c|c|}
\hline & \multicolumn{2}{|c|}{ Morphotype } \\
\hline & Dourado & Palombeta \\
\hline \multicolumn{3}{|c|}{$\alpha-E s t-1$} \\
\hline A & 0.192 & 0.412 \\
\hline B & 0.808 & 0.500 \\
\hline $\mathrm{C}$ & 0.000 & 0.088 \\
\hline $\mathrm{N}$ & 13 & 17 \\
\hline Но & 0.385 & 0.294 \\
\hline $\mathrm{He}$ & 0.323 & 0.590 \\
\hline \multicolumn{3}{|c|}{$\alpha-E s t-2$} \\
\hline A & 0.060 & 0.280 \\
\hline B & 0.840 & 0.660 \\
\hline $\mathrm{C}$ & 0.100 & 0.060 \\
\hline $\mathrm{N}$ & 25 & 25 \\
\hline Но & 0.240 & 0.200 \\
\hline $\mathrm{He}$ & 0.287 & 0.492 \\
\hline \multicolumn{3}{|c|}{$\alpha-E s t-3$} \\
\hline A & 0.542 & 0.294 \\
\hline B & 0.167 & 0.647 \\
\hline C & 0.250 & 0.059 \\
\hline D & 0.042 & 0.000 \\
\hline $\mathrm{N}$ & 12 & 17 \\
\hline Но & 0.583 & 0.235 \\
\hline $\mathrm{He}$ & 0.641 & 0.506 \\
\hline \multicolumn{3}{|c|}{$\beta$-Est-1 } \\
\hline A & 0.079 & 0.515 \\
\hline B & 0.842 & 0.439 \\
\hline $\mathrm{C}$ & 0.079 & 0.045 \\
\hline $\mathrm{N}$ & 19 & 33 \\
\hline Но & 0.158 & 0.303 \\
\hline $\mathrm{He}$ & 0.286 & 0.548 \\
\hline
\end{tabular}

Tab. 2. (continued)

\begin{tabular}{|c|c|c|}
\hline & \multicolumn{2}{|c|}{ Morphotype } \\
\hline & Dourado & Palombeta \\
\hline \multicolumn{3}{|c|}{$\beta$-Est-2 } \\
\hline A & 0.156 & 0.406 \\
\hline B & 0.781 & 0.531 \\
\hline $\mathrm{C}$ & 0.063 & 0.063 \\
\hline $\mathrm{N}$ & 16 & 16 \\
\hline Ho & 0.063 & 0.500 \\
\hline $\mathrm{He}$ & 0.373 & 0.567 \\
\hline \multicolumn{3}{|c|}{$\beta$-Est-3 } \\
\hline A & 0.833 & 0.300 \\
\hline B & 0.167 & 0.300 \\
\hline $\mathrm{C}$ & 0.00 & 0.400 \\
\hline $\mathrm{N}$ & 3 & 5 \\
\hline Ho & 0.333 & 1.000 \\
\hline $\mathrm{He}$ & 0.333 & 0.733 \\
\hline \multicolumn{3}{|c|}{ G6pd } \\
\hline A & 0.750 & 0.341 \\
\hline B & 0.250 & 0.341 \\
\hline $\mathrm{C}$ & 0.000 & 0.250 \\
\hline $\mathrm{D}$ & 0.000 & 0.068 \\
\hline $\mathrm{N}$ & 4 & 22 \\
\hline Но & 0.000 & 0.545 \\
\hline $\mathrm{He}$ & 0.429 & 0.717 \\
\hline \multicolumn{3}{|c|}{$L d h$} \\
\hline A & 0.966 & 0.867 \\
\hline B & 0.034 & 0.078 \\
\hline $\mathrm{C}$ & 0.000 & 0.011 \\
\hline $\mathrm{D}$ & 0.000 & 0.044 \\
\hline $\mathrm{N}$ & 29 & 45 \\
\hline Но & 0.069 & 0.267 \\
\hline $\mathrm{He}$ & 0.068 & 0.243 \\
\hline \multicolumn{3}{|c|}{$M d h$} \\
\hline A & 0.643 & 0.321 \\
\hline B & 0.238 & 0.393 \\
\hline $\mathrm{C}$ & 0.071 & 0.250 \\
\hline D & 0.048 & 0.036 \\
\hline $\mathrm{N}$ & 21 & 28 \\
\hline Ho & 0.381 & 0.492 \\
\hline $\mathrm{He}$ & 0.535 & 0.691 \\
\hline \multicolumn{3}{|c|}{$M e-1$} \\
\hline A & 0.833 & 0.889 \\
\hline B & 0.167 & 0.111 \\
\hline $\mathrm{N}$ & 6 & 9 \\
\hline Но & 0.000 & 0.222 \\
\hline $\mathrm{He}$ & 0.303 & 0.209 \\
\hline \multicolumn{3}{|c|}{$\mathrm{Me}-2$} \\
\hline A & 0.438 & 0.214 \\
\hline B & 0.563 & 0.571 \\
\hline $\mathrm{C}$ & 0.000 & 0.214 \\
\hline $\mathrm{N}$ & 8 & 7 \\
\hline Но & 0.375 & 0.571 \\
\hline $\mathrm{He}$ & 0.525 & 0.626 \\
\hline
\end{tabular}


Tab. 2. (continued)

\begin{tabular}{|c|c|c|}
\hline & & \\
\hline & Dourado & Palombeta \\
\hline$O d h-1$ & & \\
\hline A & 0.594 & 0.581 \\
\hline B & 0.409 & 0.371 \\
\hline $\mathrm{C}$ & 0.000 & 0.048 \\
\hline $\mathrm{N}$ & 16 & 31 \\
\hline Но & 0.063 & 0.161 \\
\hline $\mathrm{He}$ & 0.498 & 0.531 \\
\hline$O d h-2$ & & \\
\hline A & 0.864 & 0.947 \\
\hline B & 0.136 & 0.026 \\
\hline $\mathrm{C}$ & 0.000 & 0.026 \\
\hline $\mathrm{N}$ & 11 & 19 \\
\hline Но & 0.273 & 0.105 \\
\hline $\mathrm{He}$ & 0.247 & 0.104 \\
\hline Pgi & & \\
\hline A & 0.441 & 0.569 \\
\hline B & 0.412 & 0.276 \\
\hline $\mathrm{C}$ & 0.088 & 0.121 \\
\hline $\mathrm{D}$ & 0.059 & 0.034 \\
\hline $\mathrm{N}$ & 17 & 29 \\
\hline Ho & 0.647 & 0.759 \\
\hline $\mathrm{He}$ & 0.643 & 0.595 \\
\hline Pgm & & \\
\hline A & 0.705 & 0.722 \\
\hline B & 0.136 & 0.130 \\
\hline $\mathrm{C}$ & 0.091 & 0.019 \\
\hline $\mathrm{D}$ & 0.045 & 0.037 \\
\hline E & 0.023 & 0.093 \\
\hline $\mathrm{N}$ & 22 & 27 \\
\hline Но & 0.409 & 0.333 \\
\hline $\mathrm{He}$ & 0.485 & 0.460 \\
\hline Sod & & \\
\hline A & 1.000 & 1.000 \\
\hline $\mathrm{N}$ & 32 & 37 \\
\hline Но & 0.000 & 0.000 \\
\hline $\mathrm{He}$ & 0.000 & 0.000 \\
\hline Xod & & \\
\hline A & 0.194 & 0.286 \\
\hline B & 0.722 & 0.500 \\
\hline $\mathrm{C}$ & 0.083 & 0.214 \\
\hline $\mathrm{N}$ & 18 & 21 \\
\hline Ho & 0.389 & 0.571 \\
\hline $\mathrm{He}$ & 0.446 & 0.638 \\
\hline Ho (mean) & $0.257( \pm 0.050)$ & $0.382( \pm 0.061)$ \\
\hline $\mathrm{He}$ (mean) & $0.378( \pm 0.043)$ & $0.485( \pm 0.053)$ \\
\hline
\end{tabular}

However, diagnostic loci (Ayala, Powell, 1972) between morphotypes were not observed. The gene identity found among morphotypes was 0.922 , whereas the estimated number of migrants per generation was 2.623. Table 3 shows the values for the inbreeding indices (F, $\theta$ and $\mathrm{f}$ ).
Tab. 3. Inbreeding rates of Weir and Cockerham (1984) with confidence intervals for the Bootstrap averages $(\mathrm{ns}=$ non significant).

\begin{tabular}{llll}
\hline & $\mathrm{F}$ & $\theta$ & $\mathrm{f}$ \\
\hline Values (average among loci) & $0.308^{\text {ns }}$ & $0.087^{\text {ns }}$ & $0.243^{\text {ns }}$ \\
\hline Confidence interval $(95 \%)$ & {$[0.179 ; 0.428]$} & $[0.035 ; 0.136]]$ & {$[0.097 ; 0.377]$} \\
Confidence interval $(99 \%)$ & {$[0.139 ; 0.463]$} & {$[0.021 ; 0.152]$} & {$[0.049 ; 0.416]$} \\
\hline
\end{tabular}

In Table 4 are shown the probabilities of agreement with Hardy-Weinberg equilibrium for each locus and over all loci for each of the two morphotypes. Agreement with Hardy-Weinberg equilibrium was also tested taking dourado and palombeta as a single group. After the Bonferroni correction, significant differences were found only for $\beta$-Est 2 and Odh-1 loci in dourado, $\alpha-E s t-2$ and Odh-1 loci in palombeta. However, if dourado and palombeta are taken as a single group the number of loci which do not conform to Hardy-Weinberg equilibrium expectations summed up six $(\alpha-E s t-2, \alpha-E s t-3, \beta-E s t-1, M d h-3, O d h-1$ and Pgm). Linkage disequilibrium was not found between the loci.

Tab. 4. Probability (P) of Hardy-Weinberg equilibrium (Ho: random union of gametes; *: significant before Bonferroni correction; $\alpha=0.0015625$ for dourado and palombeta and $\alpha=$ 0.002777 for all samples).

\begin{tabular}{llll}
\hline Locus & Dourado & Palombeta & All Samples \\
\hline$\alpha-E s t-1$ & 1.0000 & 0.0214 & 0.0222 \\
$\alpha-E s t-2$ & 0.1261 & $0.0002^{*}$ & $0.0000^{*}$ \\
$\alpha-$ Est-3 & 0.0376 & 0.0144 & $0.0007^{*}$ \\
$\beta-$ Est-1 & 0.0206 & 0.0077 & $0.0000^{*}$ \\
$\beta$-Est-2 & $0.0006^{*}$ & 0.8136 & 0.0070 \\
$\beta-E s t-3$ & - & 1.0000 & 1.0000 \\
G6pd & 0.1429 & 0.3627 & 0.0720 \\
Ldh & 1.0000 & 1.0000 & 1.0000 \\
Mdh & 0.1826 & 0.0182 & $0.0008^{*}$ \\
Me-1 & 0.0909 & 1.0000 & 0.2031 \\
Me-2 & 0.5301 & 0.5152 & 0.1662 \\
Odh-1 & $0.0005^{*}$ & $0.0000^{*}$ & $0.0000^{*}$ \\
Odh-2 & 1.0000 & 1.0000 & 1.0000 \\
Pgi & 1.0000 & 0.0581 & 0.2652 \\
Pgm & 0.0124 & 0.0019 & $0.0000^{*}$ \\
Sod & - & - & - \\
Xod & 0.4124 & 0.4197 & 0.4233 \\
All loci & $0.0000^{*}$ & $0.0000^{*}$ & $0.0000^{*}$ \\
\hline
\end{tabular}

\section{Discussion}

The expected and observed heterozygosity values and the degree of polymorphism found for the dourado and palombeta morphotypes in this study can be considered high compared to values usually sampled in fish using allozymes as molecular markers (Ward et al., 1994). Moreover, Pla AND Pujolar (1999) analysed the genetic variation for 735 young specimens of $C$. hippurus from 
six locations in the Mediterranean Sea and the Atlantic Ocean using allozyme electrophoresis and observed low heterozygosity (mean of 0.0425 for the six populations sampled) and a low polymorphism rate $(23.33 \%$ of the loci of the six populations). The difference between the levels of genetic variation found in the present study and those found by Pla and Pujolar (1999) can be explained by the loci that were sampled. In the study by Pla AND Pujolar (1999), of the 30 loci sampled, 22 were monomorphic, whereas in the present study, only one of the 17 loci sampled had only one allele, and the two studies only sampled three enzyme systems in common ( $L d h, M d h$, and Sod). Some enzymes are known to exhibit more polymorphisms than others (Ward et al., 1992), which is the case in enzyme groups such as esterases and phosphoglucomutases. This situation applies to enzymes such as $\alpha$-Est, $\beta$-Est, and Pgi, which were used in this study and were not part of the Pla and Pujolar (1999) study. Therefore, the difference in the set of loci sampled between the two studies most likely explains the higher levels of genetic variation found in this study for the species C. hippurus.

The results related to the taxonomic classification of the morphotypes suggest homogeneity among the groups analysed. By analysing the genetic variation of different samples of the genus Coryphaena captured in the Canary Islands using allozyme electrophoresis, Pujolar and Pla (2002) recognised 11 diagnostic loci and found two species of Coryphaena at that location (C. hippurus and Coryphaena equiselis Linnaeus, 1758). Other studies using the allozyme electrophoresis method found diagnostic loci between morphotypes of Polynemus paradiseus Linnaeus, 1758 (Nahar et al., 2015) and Salmo trutta Linnaeus, 1758 (Berrebi, 2015), for example, but this was not the case in the present study.

The genetic identity value (I) found between the morphotypes was equivalent to values usually found for conspecific populations (Thorpe, 1983). Other studies have estimated the gene identity between fish groups using the allozyme electrophoresis method and have associated values of I greater than 0.85 within populations of the same species (Zawadzki et al., 2008; Erdoğan et al., 2009).

The number of migrants per generation between morphotypes also indicates homogeneity between the groups analysed. Some authors (Wright, 1931; Hartl, Clark, 2007) have noted that only one migrant per generation may be sufficient to preserve the homogeneity among gene pools and prevent geographical differentiation, and fish allozyme data have corroborated this conclusion (Lacson, 1992; Geertjes et al., 2004).

The mean values for the inbreeding rates may be considered high, although not significant, indicating a lack of preferential crosses within the morphotypes (Waples, 1998). This is a common pattern observed in conspecific fish populations analysed using allozyme electrophoresis (Waples, 1987).
The finding that deviations related to Hardy-Weinberg expectations when all sampled individuals were analyzed as a single group (Tab. 4) indicates a possible temporal Wahlund effect (Johnson, Black, 1984). Individuals of the palombeta morphotype are smaller in size (lower mean weight and smaller length), have less developed gonads (that weigh less than the dourado morphotype; data not shown), and have less advanced maturation stages (most of the individuals in non-reproductive stages, based on Beardsley Jr., 1967; data not shown) than individuals of the dourado morphotype (most of the individuals in sexual maturity stage based on Beardsley Jr., 1967; data not shown). Although there was no information about the age of the fish examined, sampled palombeta corresponds in size to averaged values for juveniles of the species $C$. hippurus (Potoschi et al., 1999), which is below the minimum size permitted for capturing dourado (IBAMA, 2003). Therefore, taken together genetic and biological data give indications that dourado and palombeta are different life stages of $C$. hippurus. Furthermore, differences were observed between the expected heterozygosity, observed heterozygosity, and effective number of alleles for the morphotypes. Within the $10 \%$ of the sampled loci which showed significant deviations from the expected Hardy-Weinberg equilibrium (twice than expected), is included the Odh-1 locus for both morphotypes. Several studies (Hochachka, 1980; Vornanen et al., 2009; Torres et al., 2012) have noted the possibility of natural selection acting on this locus in fish.

Hypotheses that involve natural selection acting on the gene frequencies of one or more loci depend on the confirmation of various conditions (Clarke, 1975; Silva, 2009). First, it must be shown that the change in gene frequencies of the locus under selection cannot be explained by simple chance. In addition, the locus under selection should be correlated with some environmental factor. Furthermore, disequilibriums in the linkage between the loci in question should also be evident. Moreover, this pattern needs to be recognised in other evolutionary units (in this case, in other species with morphotype differences). The different alleles in question should produce different phenotypes, and these differences should make sense environmentally and have an impact on adaptation.

The differences in allele frequencies and in the number of Odh alleles between the morphotypes appear to meet the first two conditions. Odh (also referred to in the literature as $A d h$, No. E.C. 1.1.1.1, alcohol NAD+ oxidoreductase) is an enzyme that participates in one of the pyruvate pathways, catalysing its reduction to ethanol (rather than lactate) in the absence of oxygen. This process helps avoid lactate accumulation in the body during anaerobic metabolism, which prevents the accumulation of this compound and the resulting muscle fatigue (Shoubridge, Hochachka, 1980). This pathway for transforming pyruvate into ethanol is found in the swimming muscles of some fish that live in $\mathrm{O}_{2}$ poor environments such as Carassius carassius Linnaeus, 1758 and Carassius auratus Linnaeus, 1758 (Vornanen et al., 2009). 
The significant differences in the $O d h$ enzyme detected between the dourado and palombeta morphotypes may be associated with the metabolism of their explosive swimming, which could be part of escape behaviour. Summing up the evidences of smaller size, less developed gonads and maturation of palombeta in relation to dourado morphotype and the evidence of genetic homogeneity among the morphotypes, give support to the hypothesis that palombeta may be a young stage of the dourado morphotype, which is possibly the adult stage of $C$. hippurus. Furthermore, natural selection could be acting on the variation observed in $O d h$ in the species, selecting over time those alleles that have a greater efficiency in converting pyruvate to ethanol rather than lactate in the swimming muscles, resulting in a decrease in the variation of this locus.

An alternative hypothesis to explain the significant differences in variation found among morphotypes is the differential expression of allozymes during the life stages of the individuals. However, this is unlikely, since no enzymes were found to be exclusive of any morphotype among the sampled loci and literature reports correlations among loci-tissues-age expression rather than differential allele's expression. Therefore, it is more conservative to interpret the differences found in genetic variation among morphotypes as a result of different gene pools rather than differential expression of any allozymes.

Returning to the conditions required to the hypotheses of natural selection, linkage disequilibrium was not observed among the loci analysed. The fourth condition (pattern be recognised in other evolutionary units), however, appears to have been met based on the study data. Most vertebrates, including fish, depend almost exclusively on aerobic metabolism. A switch to anaerobic pathways only occurs during periods of increased physical activity or low environmental oxygen levels (Torres et al., 2012). Tuna, for example, appear to have mechanisms that are very well adapted to anaerobic situations, which are used during a burst of swimming activity (Hochachka, 1980), and this may also be the case for $C$. hippurus.

The last three conditions (different alleles produce different phenotypes, they make sense in the environment and have an impact on adaptation) could not be tested in this study, which weakens the hypothesis of natural selection. Therefore, the absence of important evidence such as linkage disequilibrium and the inability to test some important conditions for the hypothesis of natural selection lead us not to reject the null hypothesis as the explanation for the differences in heterozygosity and the effective number of alleles found between the morphotypes. In other words, the differences observed can be explained by chance alone.

In short, the lack of a diagnostic locus, high genetic identity values, number of migrants per generation, and nonsignificant values for the inbreeding rates indicate the absence of preferred crossings within the morphotypes. Therefore, the null hypothesis that the morphotypes belong to the same species cannot be excluded. The amount of observed variation can be considered high in relation to that generally estimated for fish and for $C$. hippurus. This finding can be explained by the cosmopolitan and migrant behaviour of this species and the loci sampled. The differences in heterozygosity, both expected and observed, and in the effective number of alleles between the morphotypes may be related to the action of directional natural selection at the Odh locus. However, due to lack of directly related evidence needed to test this hypothesis and the limited parsimony, it was not possible to accept this hypothesis; instead, we failed to reject the null hypothesis that the differences are due to chance actions.

\section{Acknowledgments}

The authors would like to thank FIPERJ (Fundação Instituto da Pesca do Estado do Rio de Janeiro) for contributing with the samples, the fishing data and species biology. This work is financially supported by FAPERJ (Fundação de Amparo à Pesquisa do Estado do Rio de Janeiro- Processo $n^{0}$ E-26/112.613/2012 - APQ1), CAPES (Coordenação de Aperfeiçoamento de Pessoal de Nível Superior-Processo $\mathrm{n}^{0}$ 23038.007340/2011-09) and CNPq (Conselho Nacional de Desenvolvimento Científico e Tecnológico-Protocolo n ${ }^{0}$ 6139598823743844).

\section{References}

Amorim AF, Arfelli CA, Domingues RR, Piva-Silva N, MinteVera CV. Coryphaena hippurus and Acanthocybium solandri incidental catch off South and Southeast Brazil (1971-2009) by São Paulo tuna longliners. Collect Vol Sci Pap ICCAT. 2011; 66(5):2140-52.

Ayala FJ, Powell JR. Allozymes as diagnostic characters of sibling species of Drosophila. PNAS. 1972; 69(5):1094-96.

Beardsley Jr GL. Age, growth, and reproduction of the dolphin, Coryphaena hippurus, in the Straits of Florida. Copeia. 1967; (2):441-51.

Berrebi P. Three brown trout Salmo trutta lineages in Corsica described through allozyme variation. J Fish Biol. 2015; 86(1):60-73.

Clarke B. The contribution of ecological genetics to evolutionary theory: detecting the direct effects of natural selection on particular polymorphic loci. Genetics. 1975; 79(Suppl):101-13.

Díaz-Jaimes P, Uribe-Alcocer M, Rocha-Olivares A, García-deLeón FJ, Nortmoon P, Durand JD. Global phylogeography of the dolphinfish (Coryphaena hippurus): the influence of large effective population size and recent dispersal on the divergence of a marine pelagic cosmopolitan species. Mol Phylogenet Evol. 2010; 57(3):1209-18.

Duarte M, Ventura C, Silva E. Genetic variation in color morphs of the endangered species, Paracentrotus gaimardi (Echinoidea: Echinidae). Lat Am J Aquat Res. 2016; 44(1):46-55.

Erdoğan Z, Turan C, Koç HT. Morphologic and allozyme analyses of European anchovy (Engraulis encrasicolus (L. 1758)) in the Black, Marmara and Aegean Seas. Acta Adriat. 2009; 50(1):77-90. 
Fundação Instituto da Pesca do Estado do Rio de Janeiro (FIPERJ). Diagnóstico da pesca do estado do Rio de Janeiro: Projeto de monitoramento da pesca no estado do Rio de Janeiro Estatística Pesqueira. Niterói: Fundação Instituto de Pesca do Estado do Rio de Janeiro; 2013.

Geertjes GJ, Postema J, Kamping A, van Delden W, Videler JJ, van de Zande L. Allozymes and RAPDs detect little genetic population substructuring in the Caribbean stoplight parrotfish Sparisoma viride. Mar Ecol Prog Ser. 2004; 279:225-35.

Gibbs Jr RH, Collette BB. On the identification, distribution and biology of the dolphins, Coryphaena hippurus and C. equiselis. Bull Mar Sci. 1959; 9(2):117-52.

Goudet J. FSTAT, a program to estimate and test gene diversities and fixation indices (version 2.9.3) [Computer software manual - Internet]. Lausanne; 2001. Available from: http:// www2.unil.ch/popgen/softwares/fstat.htm.

Guo SW, Thompson EA. Performing the exact test of HardyWeinberg proportion for multiple alleles. Biometrics. 1992; 48(2):361-72.

Harris H, Hopkinson DA. Handbook of enzyme electrophoresis in human genetics. Amsterdam: North Holland Publishing Company; 1978.

Hartl DL, Clark AG. Principles of population genetics. Sunderland: Sinauer Associates, Inc. Publishers; 2007.

von der Heyden S, Beger M, Toonen RJ, van Herwerden L, Juinio-Meñez MA, Ravago-Gotanco R, Fauvelot C, Bernardi G. The application of genetics to marine management and conservation: examples from the Indo-Pacific. Bull Mar Sci. 2014; 90(1):123-58.

Hochachka PW. Living without oxygen: closed and open systems in hypoxia tolerance. Cambridge: Harvard University Press; 1980.

Instituto Brasileiro do Meio Ambiente (IBAMA). Portaria IBAMA Nº8-N, de 20 de março de 2003. Accessed 2016. Available from: http://www.icmbio.gov.br/cepsul/images/ stories/legislacao/Portaria/2003/p_ibama_08_2003_ revogada_tamanhominimoespeciesmarinhasestuarinas_se_s revogada_p_73_2003.pdf

Johnson MS, Black R. The Wahlund effect and geographical scale of variation in the intertidal limpet Siphonaria sp. Mar Biol. 1984; 79(3):295-302.

Kimura M, Crow JF. The number of alleles that can be maintained in a finite population. Genetics. 1964; 49(4):725-38.

Knowlton N. Molecular genetic analyses of species boundaries in the sea. Hydrobiologia. 2000; 420(1):73-90.

Krebs CJ. Ecological methodology. 2nd ed. Yorkshire: Pearson; 1999.

Lacson JM. Minimal genetic variation among samples of six species of coral reef fishes collected at La Parguera, Puerto Rico, and Discovery Bay, Jamaica. Mar Biol. 1992; 112(2):327-31.

Moritz C, Hillis DM. Molecular Systematics: Context and Controversies. In: Hillis DM, Moritz C, Mable BK, editors. Molecular Systematics. Sunderland: Sinauer Associates, Inc. Publishers; 1996. p.1-13.

Nahar A, Siddik MAB, Alam MA, Chaklader MR. Population genetic structure of paradise threadfin Polynemus paradiseus (Linneaus, 1758) revealed by allozyme marker. Int J Zool Res. 2015; 11(2):48-56.
Nei M. Genetic distance between populations. Am Nat. 1972; 106(949):283-92.

Nei M. Estimation of average heterozygosity and genetic distance from a small number of individuals. Genetics. 1978; 89(3):58390.

Nóbrega MF, Kinas PG, Lessa R, Ferrandis E. Spatial and temporal variation in artisanal catches of dolphinfish Coryphaena hippurus off north-eastern Brazil. J Fish Biol. 2015; 86(2):785-804.

Oxenford HA, Hunte W. A Preliminary investigation of the stock structure of the dolphin, Coryphaena hippurus, in the Western Central Atlantic. Fish Bull. 1986; 84(2):451-60.

Pla C, Pujolar JM. Genetic homogeneity of dolphinfish (Coryphaena hippurus) in the western Mediterranean and the eastern Atlantic. Sci Mar. 1999; 63(3-4):337-41.

Potoschi A, Reñones O, Cannizzaro L. Sexual development, maturity and reproduction of dolphinfish (Coryphaena hippurus) in the western and central Mediterranean. Sci Mar. 1999; 63(3-4):367-72.

Pujolar JM, Pla C. Occurrence of dolphinfish (Coryphaena hippurus) and pompano dolphinfish (Coryphaena equiselis) in the Canary Islands revealed by genetic analysis. N Z J Mar Freshwater Res. 2002; 36(2):339-43.

Rice WR. Analyzing tables of statistical tests. Evolution. 1989; 43(1):223-25.

Rousset F. Genepop'007: a complete re-implementation of the Genepop software for Windows and Linux. Mol Ecol Resour. 2008; 8(1):103-06.

Rousset F, Raymond M. Testing heterozygote excess and deficiency. Genetics. 1995; 140(4):1413-19.

Selander RK, Smith MH, Yang SY, Johnson WE, Gentry JR. Biochemical polymorphism and systematics in the genus Peromyscus. I: Variation in the old-field mouse (Peromyscus polionotus). Stud Genet VI Univ Texas Publ. 1971; 7103:49-70.

Shoubridge EA, Hochachka PW. Ethanol: novel end product of vertebrate anaerobic metabolism. Science. 1980; 209(4453):308-09.

Silva EP. Genética Marinha. In: Pereira RC, Soares-Gomes A, editors. Biologia Marinha. Rio de Janeiro: Interciência; 2009. p.49-70.

Swofford DL, Selander RB. Biosys-2. a computer program for the analysis of allelic variation in population genetics and biochemical systematics. Chicago: Illinois Natural History Survey; 1997.

Thorpe JP. Enzyme variation, genetic distance and evolutionary divergence in relation to levels of taxonomic separation. In: Oxford GS, Rollinson D, editors. Protein polymorphism: Adaptative and taxonomic significance. New York: Academic Press; 1983. p.131-152. (Systematics Association Special Volume Series; No. 24).

Torres JJ, Grigsby MD, Clarke ME. Aerobic and anaerobic metabolism in oxygen minimum layer fishes: the role of alcohol dehydrogenase. J Exp Biol. 2012; 215(11):1905-14.

Vornanen M, Stecyk JAW, Nilsson GN. The anoxia-tolerant crucian carp (Carassius carassius L.). In: Richards JG, Farrell AP, Brauner CJ, editors. Hypoxia. Amsterdam: Elsevier, Inc.; 2009. p.397-441. (Fish Physiology; 27). 
Waples RS. A multispecies approach to the analysis of gene flow in marine shore fishes. Evolution. 1987; 41(2):385-400.

Waples RS. Separating the wheat from the chaff: patterns of genetic differentiation in high gene flow species. J Hered. 1998; 89(5):438-50.

Ward RD, Skibinski DOF, Woodwark M. Protein heterozygosity, protein structure, and taxonomic differentiation. In: Hecht MK, Wallace B, MacIntyre RJ, editors. Evolutionary Biology. New York: Plenum Press; 1992. p.73-159.

Ward RD, Woodwark M, Skibinski DOF. A comparison of genetic diversity levels in marine, freshwater, and anadromous fishes. J Fish Biol. 1994; 44(2):213-32.

Weir BS, Cockerham CC. Estimating F-statistics with special regard to systems of mating. Evolution. 1984; 38:1358-70.
Wright S. Evolution in Mendelian populations. Genetics. 1931; 16(2):97-159.

Zawadzki CH, Renesto E, Peres MD, Paiva S. Allozyme variation among three populations of the armored catfish Hypostomus regani (Ihering, 1905) (Siluriformes, Loricariidae) from the Paraná and Paraguay river basins, Brazil. Genet Mol Biol. 2008; 31(3):767-71.
Submitted April 04, 2016

Accepted Oct 28, 2016 by Claudio Oliveira 